\title{
Influence of Product Involvement, Post Purchase Service and Consumer Personality on Dimensions of Brand Resonance for Yamaha Motor Bikes
}

T Frank Sunil Justus* and M Sadiq Ali ${ }^{\dagger}$

\section{Abstract}

Branding is the process of creating an association between a symbol, object, emotion, perception and a product or company with the goal of driving loyalty and creating differentiation. This paper takes a look at the influence of product involvement, post purchase service and consumer personality on the dimensions of brand resonance that includes brand loyalty, brand attachment, brand engagement and brand community. Companies should endeavor to create a relationship between the customer and the brand and ensure the customers are in sync with the brand. Companies should communicate with respondents even after they have purchased the vehicles and through brand communities ensure a sort of kinship with other people associated with the brand. The influence of the brand and its eventual value to the company dwell with the customers and hence companies should leave no stone unturned in their quest to develop brand feelings of loyalty, attachment, engagement and community among its customers. Further studies can be had on a pan India basis or across different states and

\footnotetext{
* Assistant Professor, Department of Business Administration, Annamalai University, Tamilnadu, India; aunl3fsj@annamalaiuniversity.ac.in † Research Scholar, Department of Business Administration, Annamalai University Tamilnadu, India; msadikalimba@gmail.com
} 
should also involve other motor cycles sold in the country.

Keywords: Product involvement, Post purchase service, Consumer personality, Brand resonance.

\section{Introduction}

Brand is a name, term, sign, symbol, or design, or a combination of them which is intended to identify the goods or services of one organization. Branding is the process of creating an association between a symbol/ object/ emotion/ perception and a product/company with the goal of driving loyalty and creating differentiation. A positive image is one which will continue to work for a company, even when things start to go wrong. A brand is more than a product, because it can have dimensions that differentiate it in some way from other products designed to satisfy the same need. Creating perceived differences among products through branding and by developing a loyal customer franchise, marketers create value that can translate to financial profits for the firm. This paper takes a look at the influence of product involvement, post purchase service and consumer personality on the dimensions of brand resonance that includes brand loyalty, brand attachment, brand engagement and brand community.

Brand resonance is characterized in terms of intensity, or the depth of psychological bond that customers have with the brand (Keller, 2011). Oliver (1997) defined brand loyalty as a deeply held commitment to rebuy or repatronize a preferred product or service consistently in the future, despite situational influences and marketing efforts having potential to cause switching behaviour. Brand attachment involves customers to go beyond behavioural loyalty having a positive attitude to viewing the brand as something special. Keller et al. (2011) divulged brand engagement as the strongest affirmation of brand loyalty that occurs when customers are willing to invest time, energy, money, or other resources in the brand beyond those expended during purchase or consumption of the brand. Brand community is based on a structured set of social relationships among admirers of a brand and is marked by a shared consciousness, rituals, traditions and a sense of moral responsibility (Schiffman \& Kanuk, 2010) 


\section{Review of literature}

Carroll and Ahuvia (2006) identified that brands which offer more in terms of symbolic benefits is identified to have higher levels of brand loyalty and positive word-of-mouth. MacInnis and Park (2005) showed brand attachment as how much a customer's intensions are strongly tied with that particular brand. Kazmer, Haythornthwaite and Shoemaker (2000) consider that a sense of belonging is beneficial for knowledge sharing in the community and that community members will be more willing to spend their time to share information with other members.

\section{Objective}

- To identify the influence of product involvement on dimensions of brand resonance.

- To identify the influence of post purchase services on dimensions of brand resonance.

- To identify the influence of consumer personality on dimensions of brand resonance.

\section{Methodology}

This study is based on the descriptive study method. An in-depth discussion was carried out by the researcher with the customers and based on the discussion and the available literature, the questionnaire was prepared. 205 questionnaires were collected from respondents of Cuddalore district, Tamil Nadu, in July 2014.

\subsection{Criteria for selection of respondents}

- Respondent should have owned an Yamaha branded two wheeler at least for a period of one year

- Respondent willing to take part in the study alone were considered

\section{Analysis}

The respondents have been classified as high and low involved by applying $\mathrm{K}$ means cluster analysis. 
Table 1: Mean and Standard deviation of brand resonance dimensions based on product involvement

Primary data computed

**Significant at one percent level

\begin{tabular}{|c|c|c|c|c|c|c|c|}
\hline \multirow{2}{*}{ 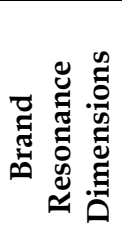 } & \multirow{2}{*}{ 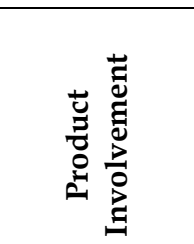 } & \multirow[b]{2}{*}{ Z } & \multirow[b]{2}{*}{$\sum^{\Xi}$} & \multirow{2}{*}{ के } & \multicolumn{3}{|c|}{$\begin{array}{c}\text { t-test for Equality of } \\
\text { Means }\end{array}$} \\
\hline & & & & & $\mathbf{t}$ & df & $\begin{array}{c}\text { Sig. } \\
\text { (2-tailed) }\end{array}$ \\
\hline \multirow{2}{*}{$\begin{array}{l}\text { Brand } \\
\text { loyalty }\end{array}$} & $\begin{array}{c}\text { Low } \\
\text { involvement }\end{array}$ & 105 & 13.52 & 1.97 & \multirow{2}{*}{$\begin{array}{c}- \\
22.104\end{array}$} & \multirow{2}{*}{203} & \multirow{2}{*}{$>.001^{* *}$} \\
\hline & $\begin{array}{c}\text { High } \\
\text { involvement }\end{array}$ & 100 & 19.83 & 2.11 & & & \\
\hline \multirow{2}{*}{$\begin{array}{c}\text { Brand } \\
\text { attach } \\
\text { ment }\end{array}$} & $\begin{array}{c}\text { B type } \\
\text { personality }\end{array}$ & 105 & 12.52 & 2.46 & \multirow[b]{2}{*}{-8.566} & \multirow[b]{2}{*}{203} & \multirow[b]{2}{*}{$>.001^{* *}$} \\
\hline & $\begin{array}{c}\text { A type } \\
\text { personality }\end{array}$ & 100 & 15.41 & 2.36 & & & \\
\hline \multirow{2}{*}{$\begin{array}{l}\text { Brand } \\
\text { commu } \\
\text { nity }\end{array}$} & $\begin{array}{c}\text { B type } \\
\text { personality }\end{array}$ & 105 & 10.99 & 2.92 & \multirow[b]{2}{*}{-8.424} & \multirow[b]{2}{*}{203} & \multirow[b]{2}{*}{$>.001^{* *}$} \\
\hline & $\begin{array}{c}\text { A type } \\
\text { personality }\end{array}$ & 100 & 14.31 & 2.71 & & & \\
\hline \multirow{2}{*}{$\begin{array}{c}\text { Brand } \\
\text { engage } \\
\text { ment }\end{array}$} & $\begin{array}{c}\text { B type } \\
\text { personality }\end{array}$ & 105 & 13.72 & 3.22 & \multirow{2}{*}{-9.149} & \multirow{2}{*}{203} & \multirow{2}{*}{$>.001^{* *}$} \\
\hline & $\begin{array}{c}\text { A type } \\
\text { personality }\end{array}$ & 100 & 17.97 & 3.42 & & & \\
\hline
\end{tabular}

From the above table it is inferred that high involvement respondents posses higher feelings of brand loyalty towards bikes as indicated by the mean value of (19.83) whereas the low involvement respondents possess a lower brand loyalty (13.52) towards bikes. $\mathrm{P}$ value indicates that there is significant difference at 1 percent level between high involvement respondents and low involvement respondents based on brand loyalty. Oliver (1999) revealed that cognitive loyalty is when the consumers think the product is the best one in the market to meet their needs and loyalty is to the information that they internalized about the product= 
High involvement respondent's have a higher feeling of brand attachment towards bikes as indicated by the mean value of (15.41) whereas the low involvement respondents possess a lower brand attachment (12.52) towards bikes and there is significant difference at 1 percent level between high and low involvement respondents based on brand attachment. Zaichkowsky (1985) inferred product involvement as the perceived personal relevance of the product, based on needs, values or interest. Fournier and Yao, (1997) studied that product involvement addresses a person's feelings towards an entire product category, such as cars, whereas brand loyalty and brand attachment focus on the brand instead of the physical product. The high involvement respondents have a higher feeling of brand community towards bikes as indicated by the mean value of (14.31) whereas the low involvement respondents possess a lower brand community (10.99) towards bikes. P value indicates that there is significant difference at 1 percent level between high involvement respondents and low involvement respondents based on brand community. The feelings of brand community start to strengthen when product involvement moves over to involve a specific brand and this relationship transcends to include likeminded others. Muniz and O'Guinn (2001) identified brand community as one that overcomes geographic restrictions and found on the set of social relationships based on the interest of a specific brand.

The high involvement respondents' have higher feelings of brand engagement towards bikes as indicated by the mean value of (17.97) whereas the low involvement respondents possess a lower brand engagement (13.72) towards bikes. $\mathrm{P}$ value indicates that there is significant difference at 1 percent level between high involvement respondents and low involvement respondents based on brand engagement. When consumers are highly involved the product becomes a part of every thought and action involving the person. Schiffman and Kanuk (2010) identified that highly involved consumers find fewer brands acceptable whereas uninvolved consumers are likely to be receptive to a great number of advertising messages regarding the purchase and will consider more brands. Consumers get involved with the product which share their passion and interest and when this involvement is higher this product involvement gives way to brand engagement. 
Richins and Bloch (1991) found that overall consumers with high product involvement were slightly more satisfied with their cars than low-involvement consumers over the term of ownership.

Table 2: Relationship between brand resonance dimensions and post purchase service

Primary data computed **Significant at one percent level

\begin{tabular}{|c|c|c|}
\hline Brand Resonance & & $\begin{array}{l}\text { Post purchase } \\
\text { service }\end{array}$ \\
\hline \multirow{2}{*}{ Brand loyalty } & R - Value & $202^{* *}$ \\
\hline & Sig & .004 \\
\hline \multirow{2}{*}{ Brand attachment } & R - Value & .110 \\
\hline & Sig & .117 \\
\hline \multirow{2}{*}{ Brand community } & R - Value & $.181^{* *}$ \\
\hline & Sig & .000 \\
\hline \multirow{2}{*}{ Brand engagement } & R - Value & $.248^{* *}$ \\
\hline & Sig & .000 \\
\hline
\end{tabular}

From the above table post purchase service is found to influence brand loyalty at one percent level. Hence respondents who perceive a better service tend to develop a feeling of brand loyalty. Parasuraman, Zeithaml and Berry (1985) found that where a combination of physical products and services were offered, such as with motor vehicles, service quality could be an important determinant of customer satisfaction. McDougall and Levesque (2000) concluded that perceived service value could be one of the important sources of a company's competitive advantage and is also an important predictor of customer satisfaction, loyalty, and financial performance.

It is found that the post purchase service does not influence feelings of brand attachment. However post purchase service is found to influence brand engagement and brand community at 1 percent level. Hence respondents who perceive a better service have a higher feeling of brand engagement and brand community.

Rust and Oliver (1994) exposed satisfaction as the customer fulfillment response which is an evaluation as well as an emotion based response to a service. Hollebeek (2010) however revealed that the level of consumer engagement at a particular point in time, 
relying on the pre-existence of customer/brand interactions, is expected to be greater in outlets characterized by higher service levels reflecting direct consumer interactions with a particular brand, and permitting greater opportunity for value co-creation. Schiffman and Kanuk (2010) revealed that it is the customer experience that provides meaning to the brand community rather than the brand itself.

Table 3: Mean and standard deviation of brand resonance dimensions based on Type A and Type B personality.

Primary data

**Significant at one percent level *Significant at five percent level

\begin{tabular}{|c|c|c|c|c|c|c|c|}
\hline \multirow{2}{*}{ 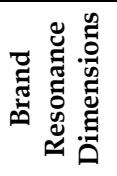 } & \multirow{2}{*}{ 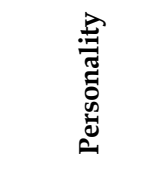 } & \multirow[b]{2}{*}{$\mathbf{Z}$} & \multirow[b]{2}{*}{$\stackrel{\Xi}{\Sigma}$} & \multirow{2}{*}{ क्ञ } & \multicolumn{3}{|c|}{ t-test for Equality of Means } \\
\hline & & & & & $\mathbf{t}$ & df & $\begin{array}{c}\text { Sig. } \\
\text { (2-tailed) }\end{array}$ \\
\hline \multirow{2}{*}{ 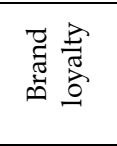 } & $\begin{array}{l}\text { B type } \\
\text { personality }\end{array}$ & 114 & 16.09 & 3.36 & \multirow{2}{*}{-2.204} & \multirow{2}{*}{203} & \multirow{2}{*}{$.029^{*}$} \\
\hline & $\begin{array}{l}\text { A type } \\
\text { personality }\end{array}$ & 91 & 17.24 & 4.14 & & & \\
\hline \multirow{2}{*}{ 壳 } & $\begin{array}{l}\text { B type } \\
\text { personality }\end{array}$ & 114 & 13.68 & 2.69 & \multirow[b]{2}{*}{-1.417} & \multirow[b]{2}{*}{203} & \multirow[b]{2}{*}{158} \\
\hline & $\begin{array}{l}\text { A type } \\
\text { personality }\end{array}$ & 91 & 14.24 & 2.93 & & & \\
\hline \multirow{2}{*}{ 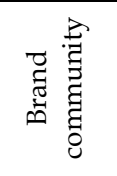 } & $\begin{array}{l}\text { B type } \\
\text { personality }\end{array}$ & 114 & 12.06 & 3.07 & \multirow[b]{2}{*}{-2.731} & \multirow[b]{2}{*}{203} & \multirow[b]{2}{*}{$.007^{* *}$} \\
\hline & $\begin{array}{l}\text { A type } \\
\text { personality }\end{array}$ & 91 & 13.30 & 3.39 & & & \\
\hline \multirow{2}{*}{ 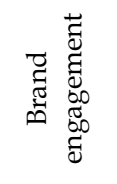 } & $\begin{array}{l}\text { B type } \\
\text { personality }\end{array}$ & 114 & 15.48 & 3.68 & \multirow{2}{*}{-1.274} & \multirow{2}{*}{203} & \multirow{2}{*}{.204} \\
\hline & $\begin{array}{l}\text { A type } \\
\text { personality }\end{array}$ & 91 & 16.19 & 4.22 & & & \\
\hline
\end{tabular}

From the above table it is observed that ' $A$ ' type personality respondents have a higher feeling of brand loyalty compared to ' $\mathrm{B}$ ' type personality respondents as indicated by the mean values. There is significant difference at five percent level between ' $A$ ' and ' $B$ ' type respondents based on $P$ value. Robbins (2007) revealed that 
Type A personality respondents because of their concern for quantity and speed rely on past experiences rather than allocating time to develop unique solutions. ' $\mathrm{A}$ ' type personality respondents have higher brand community feelings than $\mathrm{B}$ type personality. $\mathrm{P}$ value indicates that there is significant difference at one percent level between $\mathrm{A}$ and $\mathrm{B}$ type personality respondents based on brand community feelings. Newstrom (2006) identified that type A's enjoy their success so much that they disregard their surrounding stress. Keller et al. (2011) put forth that the length of time to build a strong brand will be directly proportional to the amount of time it takes to create sufficient awareness and understanding so that firmly held and felt beliefs and attitudes about the brand are formed.

Both brand engagement and brand attachment feelings are higher for A type personality Yamaha users based on mean values. However $P$ value indicates no significant difference between $B$ type and A type personality respondents based on brand engagement and brand attachment feelings. Booth-Kewley (1987) revealed that the research on type A and type B people is still accumulating. Schiffman and kanuk (2010) revealed that individuals are more likely to buy brands whose personalities intimately match their own self images

\section{Findings}

- Respondents with a high product involvement have higher feelings of brand loyalty, brand attachment, brand community and brand engagement

- A higher perceived service is found to influence brand loyalty, brand attachment and brand community

- 'A' type personality respondents have higher feelings of brand loyalty, brand attachment, brand community and brand engagement

\section{Suggestions}

- Yamaha should create products that stand out from the crowd in terms of power and performance which ensures 
the customers are highly involved to the product in which case customers become ambassadors and help communicate the brand to others.

- Companies should have well trained personnel to man their service outlets. The personnel should be trained to properly communicate the maintenance needs of the vehicles. A satisfied service experience is a sure way to build a brand.

- Companies should come out with multiple models so that consumers will be able to choose a product that matches with their personality and in turn develop a lasting bond with the brand.

- The product should be differentiated from other offerings in the market in terms of design, power, engine tone and ride comfort in order to create a powerful brand

- Companies should be active in fostering brand communities. Brand community counsellors should be provided who can help customers in camp activities. Brand community creates a bond between Yamaha owners and a) the bike b) brand Yamaha c) Yamaha the company and d) other Yamaha owners.

\section{Conclusion}

Companies should have a careful plan in developing ways and means to build product that result in strong brand building. Companies should endeavour to create a relationship between the customer and the brand and ensure that the customers are in sync with the brand. Companies should communicate with respondents even after they have purchased the vehicles and through brand communities ensure a sort of kinship with other people associated with the brand. The influence of the brand and its eventual value to the company dwell with the customers and hence companies should leave no stone unturned in their quest to develop brand feelings of loyalty, attachment, engagement and community among its customers. Further studies can be had on a pan India basis or across different states and should also involve other motor cycles sold in the country. 


\section{References}

Booth-Kewley, S. \& Friedman, H. S. (1987). Psychological predictors of heart disease: A quantitative review. Psychological Bulletin, 101(3), 343 $-62$

Fournier, Susan, \& Yao, J. L. (1997). Reviving brand loyalty: A reconceptualization within the framework of consumer-brand relationships. International Journal of Research in Marketing, 14(5), 451472.

Hollebeek, L. D. (Feb. 2010) $5^{\text {th }}$ International Academy of Wine Business Research Conference, Auckland (NZ)

Kazmer, M. M., Haythornthwaite, C. J. \& Shoemaker, S. (2000). Community development among distance learners: Temporal and technological dimensions. Journal of Computer Mediated Communication, 6(1), 25-43.

Keller. K. L., Parameswaran, M. G., \& Isaac J., (2011). Strategic Brand Management, New Delhi: Pearson Education.

MacInnis, D. J \& Park, C. W. (2005). The ties that bind: Measuring the strength of consumers' attachments to brands. Journal of Consumer Psychology, 15(1), 77-91.

McDougall, G. H. G., \& Levesque, T. (2000). Customer satisfaction with services: Putting perceived value into the equation. Journal of Services Marketing, 14(5), 392-410.

Muniz, A. M., \& O'Guinn, T. C. (2001). Brand community. The Journal of Consumer Research, 27(4), 412-432.

Newstrom, John W., \& Keith Davis (2006). Organizational behavior. New Delhi: Tata McGraw Hill

Oliver, R. L. (1997). A behavioural perspective on the consumer. New York: McGraw-Hill.

Oliver, R. L., (1999). Whence consumer loyalty? Journal of Marketing, 63(4) pp 33-44.

Parasuraman. A., Zeithaml. V. A., and Berry L. L., (1985). A conceptual model of service quality and its implication for future research, Journal of Marketing, 49(4), 40 - 50.

Richins, M. L., \& Bloch, P. H. (1986). After the new wears off: The temporal context of product involvement. Journal of Consumer Research, 13(2), 280-285.

Robbins, S. P., \& Timothy J. (2007). Organizational behavior. New Delhi: Prentice Hall of India

Rust R. T. \& Oliver R. L. (1994) Service quality: Insights and managerial implication from the frontier. In Rust R. T. \& Oliver R. L. Eds Service Quality: New directions in theory and practice, Sage Publications, London, 241 - 268 
T Frank Sunil Justus et al.

Influence of Product Involvement

Schiffman, G. L. \& Kanuk, L. L. (2010) Consumer behaviour. New Delhi: Pearson Education

Zaichkowsky, J. L. (1985) Measuring the involvement construct. Journal of Consumer Research, 12(December), pp. 341-352. 